\title{
Minimally Invasive Spinal Fusion Technique in Patients with Lumbar Segmental Instability
}

\author{
Mohammed Hassan ${ }^{2, *}$ MSc; Adnan Sebaie ${ }^{1}$ MD ; Mahmoud Seddik ${ }^{1}$ MD ; Ahmed Akar ${ }^{1}$ MD
}

*Corresponding Author:

Mohammed Hassan

dr_mhsaad_ortho@yahoo.com

Received for publication August 4, 2020; Accepted September 29, 2020; Published online September 29, 2020.

Copyright 2020 The Authors published by Al-Azhar University, Faculty of Medicine, Cairo, Egypt. All rights reserved. This an openaccess article distributed under the legal terms, where it is permissible to download and share the work provided it is properly cited. The work cannot be changed in anyway or used commercially.

doi: 10.21608 /aimj.2020.37869.1289

${ }^{1}$ Orthopedic Surgery Department, Faculty of Medicine, Al-Azhar University, Cairo, Egypt.

2 Orthopedic Surgery Department, Shuobra general hospital, Cairo, Egypt.

Disclosure: The authors have no financial interest to declare in relation to the content of this article. The Article Processing Charge was paid for by the authors.

Authorship: All authors have a substantial contribution to the article.

\begin{abstract}
Background: Lumbar spinal fusion is a common surgical procedure for treatment of lower back pain caused by degeneration of lumbar disc. The aim of fusion is to prevent motion in the destabilized segments to decrease the low back pain. A modified interspinous device can provide stabilization similar to pedicular screw fixation avoiding its complication when used for interbody fusion as a minimally invasive procedur.

Aim of work is to investigate using a new fusion technique, consist of trans-foraminal inter-body placement of peek cage and interspinous stabilization by rigid interspinous device which could provide stabilization of the posterior spinal elements similar to pedicle screw fixation as a minimally invasive procedure.

Patient and Methods: The study involved 20 patients with signs of moderate segmental instability in lumbar spine .Transforaminalinterbody fusion using the polyethere- therketone( PEEK )cage and rigid interspinous device fixation was performed. Patients were followed up and treatment outcomes were assessed within approximately 24 months after surgery.

Results: According to pain intensity level on the visual analogue scale, the need for painkillers and the quality of life according to the Oswestry Disability Index scale during the early postoperative period demonstrated significantly better outcomes due to a less severe operative trauma to the paravertebral soft tissues. The formation of interbody bone formation was observed after $20-36$ months in $94 \%$ of patients . Postoperative complications occurred in $2.2 \%$ of patient.

Conclusion: The use of transforaminalinterbody fusion and rigid interspinous stabilization provides better clinical outcomes and fewer postoperative complications in patients with moderate lumbar segmental instability.
\end{abstract}

Keywords: segmental instability; lumbar spine ; degenerative disc disease ;TLIF ; rigid interspinous fixation.

\section{INTRODUCTION}

The study of the causes of the low back pain revealed that $80-90 \%$ of lumbosacral pain cases are associated with intervertebral disc pathology, including segmental instability to be present in more than a half of the patients. ${ }^{12,3,4,5}$

The modern approach for treatment lumbar segmental instability includes inter-body cage placement and trans- pedicular fixation of the affected spine segment. ${ }^{6,}$ This type of fusion is

associated with significant damage to paravertebral soft tissue, the muscles and ligaments, which results in significant paravertebral adhesive changes.

This changes lead to long period of healing and recovery and can worsen patients quality of life and affect their working capacity. ${ }^{8,9}$
The search for new techniques to have a good results of patients with symptomatic lumbar segmental instability is planning to develop effective stabilization of the operated segment with minimal trauma to the surrounding tissues.

The aim of this study to investigate using a new fusion technique, consist of trans-foraminal interbody placement of peek cage and interspinous stabilization by rigid interspinous device which can provide stabilization of the posterior spinal elements similar to pedicle screw fixation as a minimally invasive procedure.

\section{PATIENT AND MATERIALS}

This study was conducted between 2014and 2019 in Al-Azhar university hospitals , Cairo, Egypt. The 
study included 20 patients who meet the inclusion criteria, but not the exclusion criteria, using TLIF with a modified interspinous device fixation. The protocol was discussed and approved for clinical study by the Ethical Research Committee of AlAzhar University and a written informed consent was obtained. All patients were informed about the pathology and the suggested treatment according to their diagnosis and also informed about the possible complications. Inclusion criteria were as follows: signs of moderate segmental instability: grade I spondylolisthesis according to grade $\mathrm{H}$. Meyerding (without spondylolysis) (figure1)and herniation or protrusion of the intervertebral disc followed by disc space or spinal canal narrowing that causes corresponding clinical symptoms (Figure2). Exclusions criteria include degenerative Spondylolisthesis greater than grade I according to Meyerding classification, any forms of isthmic spondylolisthesis, Prior decompressive laminectomy, hemilaminectomy or significant lamina fenestration which weakens the spinous process, Use in more than one level ,Cases of L5/S1as sacral 1 vertebra has no spinous process and Segmental stabilization without interbody fusion.

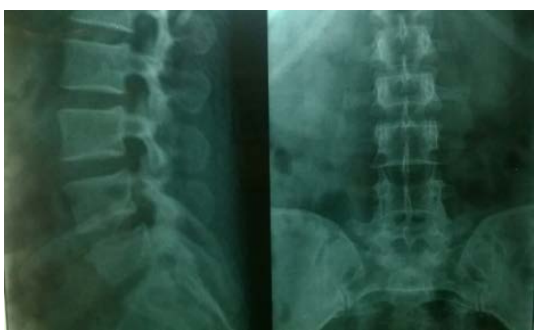

Fig 1: Preoperative lumbar spine $\mathrm{x}$-ray : antero posterior and lateral views showing : grade I spondylolisthesis at level L4-L5.
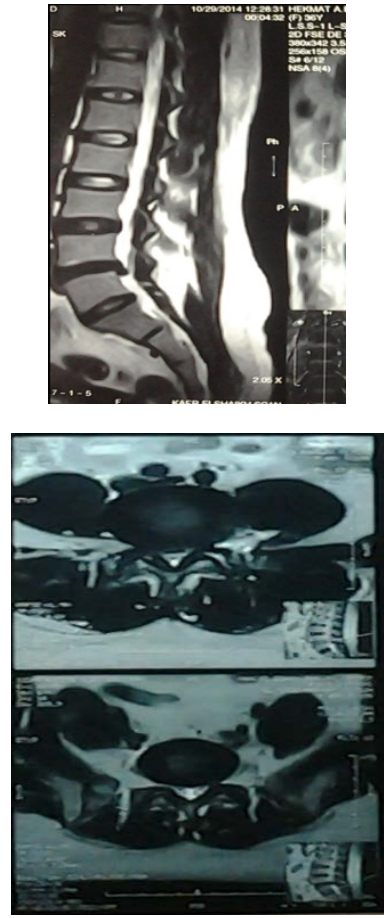

Fig 2: Preoperative magnetic resonance imaging (MRI) lumbosacral showing herniation of the intervertebral disc L4-L5 with spinal canal narrowing.

The patients were undergo transforaminalinterbody fusion using PEEK cage. The inner cavity of the cage was filled with the bone autograft obtained from surgical approach. The patients underwent decompression via unilateral access using an original technique $^{10}$ in the extent of unilateral partial facetectomy followed by stabilization with the modified rigid interspinous implant. After surgery, follow-up was after 6 weeks, 6 months, 12 months, 18 months and 24 months postoperative. radiographic parameters for assessing the bone block formation capability were also assessed. A Clinical parameters were also assessed: the severity of pain according to the visual analog scale (VAS), the need for painkillers according to the number of nonsteroidal anti-inflammatory drug injections per day, and the quality of life in patients with low back pain according to the Oswestry index(ODI).,11

The statistical difference was calculated using two methods: 1)the Student's unpaired t-test for variables which were continuous and followed a normal distribution.2) Mann-Whitney U test for those not following a normal distribution. If P-value was less than 0.05 , this was considered significant.

\section{RESULTS}

All 20 patients included in this study had intermediate term follow up till 24months postprocedure. Preoperative symptoms were back pain in all cases (100\%). Back pain was associated with leg pain (radiculopathy) in 15 (75\%) patients, hypothesia or sensory loss in $10(50 \%)$ patients, lower extremity muscle weakness in 5 (25\%). Two weeks after the procedure $50.0 \%$ of patients reported improvement of their back pain, radiculopathy improved in $60.0 \%$ of patients and sensory loss improved in $30.0 \%$ of patients. Assessment was mainly subjective using the VAS for pain assessment at 6 weeks, 6 months, 12 months and 18 months, 24 months ( Table 1) (Figure3).

Also using the ODI for disability and quality of life assessment at 6 weeks, 6 months, 12 months and 18 months, 24 months postoperatively ( Table 2) (Figure4). During follow-up (mean time of 24 months), control X-ray pictures of the spine in the patients revealed no dislocation and migration of an implant, a well as no signs of segmental instability. The interbody bone block formation was detected in $86 \%$ of the patients $10-15$ months after surgery and in $94 \%$ of patients the bone block formation was detected $20-36$ months after surgery. (Figure 5)

After interbody fusion and rigid interspinous stabilization, one (2.2\%) complication was verified as a postoperative wound infection on the background of subcompensated type 2 diabetes. Local application of antiseptics and prolonged antibiotic course enabled to stop the inflammatory process. 


\begin{tabular}{|c|c|c|c|c|}
\hline & \multicolumn{2}{|l|}{ VAS } & \multicolumn{2}{|c|}{ Paired t-test } \\
\hline & Range & $\begin{array}{l}\text { Mean } \\
\pm \text { SD }\end{array}$ & $\mathrm{T}$ & $\begin{array}{l}\text { P- } \\
\text { Value }\end{array}$ \\
\hline Preoperative & $\begin{array}{l}4.0- \\
9.0\end{array}$ & $\begin{array}{l}6.4 \pm \\
1.792\end{array}$ & \multirow[b]{2}{*}{3.656} & \multirow[b]{2}{*}{0.000} \\
\hline $\begin{array}{l}\text { After } 6 \\
\text { weeks }\end{array}$ & $\begin{array}{l}3.0- \\
7.0\end{array}$ & $\begin{array}{l}4.5 \pm \\
1.357\end{array}$ & & \\
\hline Preoperative & $\begin{array}{l}4.0- \\
9.0\end{array}$ & $\begin{array}{l}6.4 \pm \\
1.792\end{array}$ & \multirow[b]{2}{*}{8.732} & \multirow[b]{2}{*}{0.000} \\
\hline $\begin{array}{l}\text { After } 6 \\
\text { months }\end{array}$ & $\begin{array}{l}1.0- \\
4.0\end{array}$ & $\begin{array}{l}2.45 \pm \\
1.099\end{array}$ & & \\
\hline Preoperative & $\begin{array}{l}4.0- \\
9.0\end{array}$ & $\begin{array}{l}6.4 \pm \\
1.792\end{array}$ & \multirow[b]{2}{*}{11.037} & \multirow[b]{2}{*}{0.000} \\
\hline $\begin{array}{l}\text { After } 12 \\
\text { months }\end{array}$ & $\begin{array}{l}1.0- \\
3.0\end{array}$ & $\begin{array}{l}1.8 \pm \\
0.767\end{array}$ & & \\
\hline Preoperative & $\begin{array}{l}4.0- \\
9.0\end{array}$ & $\begin{array}{l}6.4 \pm \\
1.792\end{array}$ & \multirow[b]{2}{*}{12.943} & \multirow[b]{2}{*}{0.000} \\
\hline $\begin{array}{l}\text { After } 18 \\
\text { months }\end{array}$ & $\begin{array}{l}1.0- \\
2.0\end{array}$ & $\begin{array}{l}1.3 \pm \\
0.470\end{array}$ & & \\
\hline Preoperative & $\begin{array}{l}4.0- \\
9.0\end{array}$ & $\begin{array}{l}6.4 \pm \\
1.792\end{array}$ & \multirow[b]{2}{*}{15.075} & \multirow[b]{2}{*}{0.000} \\
\hline $\begin{array}{l}\text { After } 24 \\
\text { months }\end{array}$ & $\begin{array}{l}0.0- \\
1.0 \\
\end{array}$ & $\begin{array}{l}0.25 \pm \\
0.444 \\
\end{array}$ & & \\
\hline
\end{tabular}

Table 1: Comparison between VAS preoperative and after6 weeks, 6 months, 12 months, 18 months and 24 months postoperative.

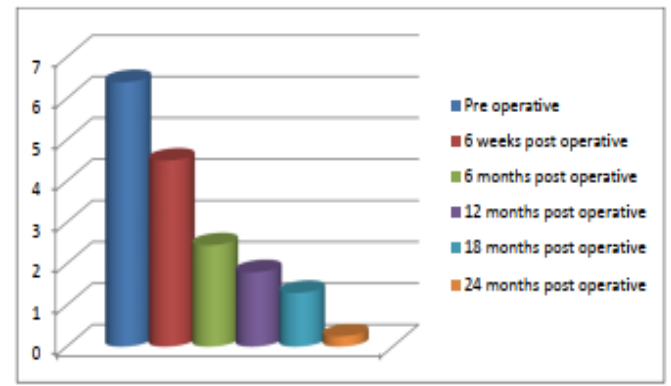

Fig 3: Comparison between VAS preoperative and after6 weeks, 6 months, 12 months, 18 months and 24 months postoperative .

\begin{tabular}{|c|c|c|c|c|}
\hline & \multicolumn{2}{|l|}{ ODI } & \multicolumn{2}{|c|}{ Paired t-test } \\
\hline & Range & $\begin{array}{l}\text { Mean } \pm \\
\text { SD }\end{array}$ & $\mathrm{T}$ & $\begin{array}{l}\text { P- } \\
\text { Value }\end{array}$ \\
\hline Preoperative & $22-38$ & $\begin{array}{l}30 \pm \\
5.331\end{array}$ & \multirow[b]{2}{*}{16.436} & \multirow{2}{*}{0.000} \\
\hline $\begin{array}{l}\text { After } 6 \\
\text { weeks }\end{array}$ & $13-19$ & $\begin{array}{l}16.8 \pm \\
2.330 \\
\end{array}$ & & \\
\hline Preoperative & $22-38$ & $\begin{array}{l}30 \pm \\
5.331 \\
\end{array}$ & \multirow{2}{*}{12.847} & \multirow{2}{*}{0.000} \\
\hline $\begin{array}{l}\text { After } 6 \\
\text { months }\end{array}$ & $8-17$ & $\begin{array}{l}12.5 \pm \\
2.946 \\
\end{array}$ & & \\
\hline Preoperative & $22-38$ & $\begin{array}{l}30 \pm \\
5.331\end{array}$ & \multirow{2}{*}{14.316} & \multirow{2}{*}{0.000} \\
\hline $\begin{array}{l}\text { After } 12 \\
\text { months }\end{array}$ & $6-15$ & $\begin{array}{l}10.5 \pm \\
2.946\end{array}$ & & \\
\hline Preoperative & $22-38$ & $\begin{array}{l}30 \pm \\
5.331 \\
\end{array}$ & \multirow{2}{*}{17.766} & \multirow{2}{*}{0.000} \\
\hline $\begin{array}{l}\text { After } 18 \\
\text { months }\end{array}$ & $2-10$ & $\begin{array}{l}6.3 \pm \\
2.677 \\
\end{array}$ & & \\
\hline Preoperative & $22-38$ & $\begin{array}{l}30 \pm \\
5.331 \\
\end{array}$ & \multirow{2}{*}{6.862} & \multirow{2}{*}{0.000} \\
\hline $\begin{array}{l}\text { After } 24 \\
\text { months }\end{array}$ & $1-5$ & $\begin{array}{ll}3.1 \pm \\
1.165 \\
\end{array}$ & & \\
\hline
\end{tabular}

Table 2: Comparison between ODI preoperative and after6 weeks, 6 months, 12 months, 18 months and 24 months postoperative.

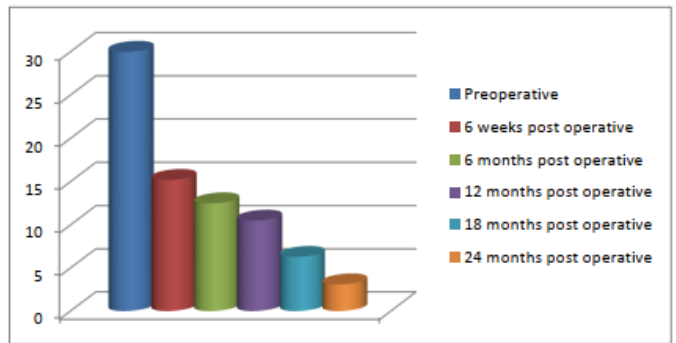

Fig 4: Comparison between ODI preoperative and after 6 weeks, 6 months, 12 months, 18 months and 24 months postoperative

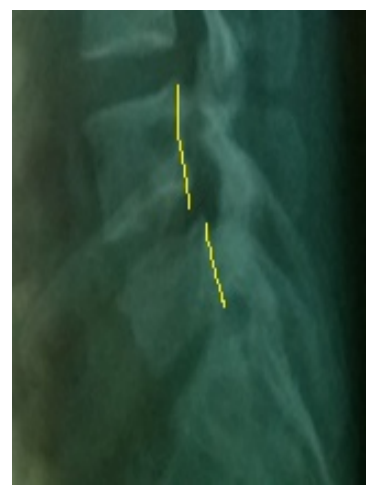

A

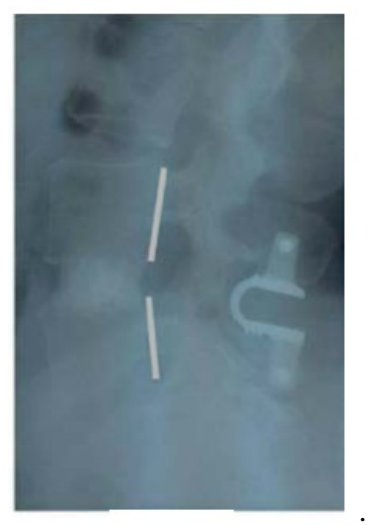

B

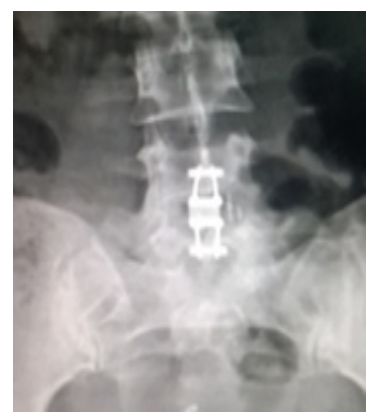

C

Fig 5: A-before surgery (anterior translation of the L4 above L5 level,5 mm) B- 20 months after the L4-L5 interbody fusion using the peek cage and rigid interspinous fixation : no translation at the L4L5 level and X-ray signs of bone block formation.

C- anteroposterior view after surgery at the L4-L5 level and signs of bone block formation. 


\section{DISCUSSION}

The study of new techniques of treatment for degenerative segmental spinal instability is linked to the lack of standard treatment approaches in the updated spine medicine, as well as to the efforts to improve the effectiveness of surgical methods followed by negative outcomes in $3-20 \%$ of cases according to different authors. ${ }^{8,9}$ These complications are associated with the insufficient interbody bone formation and with recurrence of the same neurological symptoms, and infection after surgery. The indications for decompression and fixation surgery, which is based on studying the severity of degeneration of the elements in lumbar spine , outcomes of surgical treatment, and mechanisms of fusion, cause decrease in complictions mentioned before ${ }^{7,8,9}$ It was found that the success of surgery for symptomatic instability in the SMS depends not only on decompression of neural structures in the intervertebral disc spaces and spinal canal, but also on the well performed surgical procedure, i.e. reconstruction and stabilization of the disc space between lumbar spine. ${ }^{7,20}$ Significant intraoperative trauma, as well as a relatively high risk of early and late complications in the form of recurrent spinal stenosis, insufficient bone block formation, and pseudoarthrosis formation limits the use of open transpedicular fixation at the first signs of segmental lumbar instability. ${ }^{2,10,15}$ There is a direct correlation between the degree of resection of structural elements of the lumbar spinal motion segment and the development of instability postoperative in the case of reconstruction of the spinal canal via posterior surgical approach. ${ }^{15,20,21,22}$ In such cases, there are indication for stabilization procedure followed by rigidor dynamic transpedicular fixation via either openor percutaneous accessin most cases. ${ }^{12,13,14,15}$ The well functional recovery of patients after open transpedicular fixation is played by the following factors as Severity of intraoperative trauma to the muscles and ligaments, Adequate correcting the segmental instability and adequate bone block formation and its stability within prolonged time. ${ }^{7,23}$ Biomechanical studies have shown that a single transpedicular fixation in the case of unstable SMSs causes more stresses on the pedicle screws, resulting in its breakage (up to $10 \%$ of cases) and failure of the stabilization system. ${ }^{11,12,13,24}$ In order to avoid such complications, the new concept of rigid fixation combines interbody fusion and transpedicular fixation techniques regarded as "gold standard" of treatment for segmental spinal instability. ${ }^{14,15}$ The progression of the degenerative disc disease causes decrease the size of the interbody space gradually and also the neural foramines. ${ }^{5,18}$ Treatment options for correcting the height of disc space include placement of osteoinductive or osteoconductive materials. ${ }^{14,16} \mathrm{~A}$ bone autograft was initially inserted into a disc space in order to form the fusion, but the tendency of resorption of the autograft and the high rate of development pseudarthrosis caused the use of threaded cages. ${ }^{23}$. ${ }^{25,26}$ Interbody cage placement causes indirect decompression to the disc space and spinal nerve roots by increasing the height of the intervertebral disc. ${ }^{5,13}$ This approach allow quick and proper fixation of the segment, increased the effectiveness of treatment, and reduced postoperative bed rest. 24,26,27 The more invasive procedur of bilateral placement of threaded cages and the risks of implant displacement after a wide decompression of the spinal canal required further search for interbody fusion options. ${ }^{28,29,30}$ The routine method of transforaminal fusion uses a threadless bean-shaped cage, which is placed by unilateral transforaminal access. PEEK cages became more popular due to physical and chemical features, such as full biocompatibility , absence of cytotoxic and mutagenic effects and parameters in biomechanics similar to those of a bone. ${ }^{31,32}$

The Treatment results of patients with posterior interbody stabilization are various. In 1985, Blume develop the unilateral transforaminal access with placement of a bean-shaped cage into the intervertebral disc space that was followed by transpedicular fixation as a search for a less traumatic posterior interbody fusion technique. ${ }^{33,34,}$

T. Lowe et al.found that the TLIF procedure have fusion rate reaches $90 \%$ with good and excellent clinical outcomes being observed in $85 \%$ of patients. $15,20,35$

In recent years, became popular using different interspinous implants for stabilization procedure after microsurgical discectomy. ${ }^{36,37,38}$ In the same time , titanium U-shaped constructs accepted due to the capability of intralaminar placement. ${ }^{2,39,40,41}$ Using of these implants allows some actions as widening the size of the spinal canal and disc spaces by widening the posterior and middle parts of disc spaces without kyphosis developmentand restricting the SMS movement in sagittal plane. ${ }^{2,39}$

There is indications for using interspinousimplants :preventive measures for the adjacent segment syndrome after rigid stabilization, grade I degenerative spondylolisthesis, spinal stenosis, initial instability in the SMS or preventive measures after discectomy and degenerative facet disease ${ }^{38}$ $, 40,41,43$ Contraindications to the interspinous stabilization are regarded as follows: signs of osteoporosis, vertebral body fractures and grade IIIV spondylolisthesis. ${ }^{37,39}$

Compared to the conventional TLIF technique, the advantages of rigid interbody fusion with interspinous stabilization are as follows:Minimally invasive as Less traumatic surgical approach ,Simple rigid interspinous implant placement with less supplementary surgical instruments, Effective unstable segment fixation and high incidence of bone block formation and fewer postoperative complications. 


\section{CONCLUSION}

Using both transforaminalinterbody fusion and rigid interspinous stabilization for treatment of symptomatic lumbosacral degenerative disc disease combined with moderate segmental instability enables to achieve better clinical outcomes and causes fewer postoperative complications.

\section{REFERENCES}

1. Minaeva N.G. Initiative to the lower back pain. World Health Organization, the Department of Noncommunicable Diseases Nevrologicheskiyzhurnal. 2001;6(3):53-7. In Russian.

2. Byval'tsev V.A., Sorokovikov V.A., Kalinin A.A., Egorov A.V., Belykh E.G. PanasenkovS.Yu, Comparative analysis of the outcomes of decompression surgery and simultaneous decompression and stabilization surgery in the treatment for disc-radicular conflict in the lumbosacral spine. Bulletin of the Scientific Center of Reconstructive and Restorative Surgery, Siberian Branch, Russian Academy of Medical Sciences. 2011;1(80):38-43. In Russian.

3. Wilmink JT. MR imaging of the spine: trauma and degenerative disease. Europ Radiology. 1999;9(7):1259-66. doi.10.1007/s003300050832

4. Resnick DK, HaidRWJr, Wang JC. Surgical management of low back pain. New York: Thieme 2008;210. doi.10.1007/s00590-009-0535-6.

5. Konovalov N.A., Shevelev I.N., Kornienko V.N., Nazarenko A.G. Clinical and diagnostic assessment of the severity of degenerative lumbosacral spine lesions. Annalyklinicheskoy I eksperimental'noynevrologii. . 2009;1:16-21. In Russian

6. Park Y, Ha JW. Comparison of one-level posterior lumbar interbody fusion performed with a minimally invasive approach or a traditional open approach.Spine.2007;32:537-43. doi.10.1097/01.brs. 0000256473. 49791.f4.

7. Pellise F, Hernandez A, Vidal X, Minguell J, Martínez C, Villanueva C. Radiologic assessment of all nonfused lumbar segments 7.5 years after instrumented posterior spinal fusion. Spine. 2007;32:574-579.doi.10.1097/01.

brs.0000256875.17765.e6.

8.Van den Hauwe L. Pathology of the Posterior Elements. Medical Radiology 2007;157-84. doi.10.1007/978-3-540-68483-1_7.

9. Fritsch EW, Heisel J, Rupp S. The failed back surgery syndrome: reasons, intraoperative findings and long-term results: a report of 182 operative treatments. Spine.1996; 1:626-33. doi.10.1097/00007632-199603010-00018.

10. Kalinin A.A., Byval'tsev V.A., Sorokovikov V.A., Belykh E.G. Surgical approach to the spinal canal for lumbosacral stenosis. Patent No 2508909(priority of November 12, 2012), registered in the Bulletin No 7, March 10, 2014

11. Byval'tsev V.A., Belykh E.G., Alekseeva N.V., Sorokovikov V.A. The use of scales and questionnaires for examining patients with degenerative lesions in the lumbar spine: Textbook. Irkutsk: NC RVKh SO RAMN 2013; 32

12. Simonovich AE. The use of porous NiTi implants for surgical treatment of degenerative disc disease in the lumbar spine. Khirurgiyapozvonochnika 2004;4:8-17. In Russian.

13. Kim DH, Jeong ST, Lee SS. Posterior Lumbar Interbody Fusion using Unilateral Single Cage and Local Morselized Graft. Clinics in Orthopedic Surgery. 2009;1(4): 214-22.

14. Logroscino CA, Proietti L, Pola E, Scaramuzzo L, Tamburrelli FC. A minimally invasive posterior lumbar interbody fusion for degenerative lumbar spine instabilities.Eur Spine J. 2011;20(1):41-5.

15. Park Y, Ha JW, Lee YT, Oh HC, Yoo JH, Kim HC. Surgical Outcomes of Minimally Invasive TransforaminalLumbar Interbody Fusion for the Treatment of Spondylolisthesis and Degenerative Segmental Instability. Asian Spine J. 2011;5(4):22836.

16. Krut'ko AV. The outcomes of decompression and stabilization surgery using unilateral approach for lumbar spinal stenosis. Voprosyneyrokhirurgiiim NN Burdenko. 2012;2:33-41. In Russian.

17. Lee SG, Park CW, Kim WK. Minimally Invasive Multilevel Percutaneous Pedicle Screw Fixation for Lumbar Spinal Diseases. Korean $J$ Spine 2012;9(4):352-7.

18. Marchi L, Abdala N, Oliveira L, Amaral R, Coutinho E, Pimenta L. StandAlone Lateral Interbody Fusion for the Treatment of Low-Grade Degenerative Spondylolisthesis. The Scientific World J. 2012; Article ID 456346:1-7.

20. Krut'ko AV. Comparative analysis of posterior lumbar interbody fusion(PLIF) and transforaminal lumbar interbody fusion (TLIF) combined with transpedicular fixation. Vestniktravmatologii $i$ ortopediiim N NPriorova 2012;1:12-21. In Russian.

21. Byval'tsev VA, Sorokovikov VA, Egorov AV, Belykh EG, Panasenkov S, Yu, Kalinin AA, Murzin AA. Comparative analysis of the effectiveness of endoscopic, microsurgical, and endoscopicallyassisted discectomy in the treatment of patients with lumbar disc herniations. 
Voprosyneyrokhirurgiiim N NBurdenko. 2010;4:2026. In Russian.

$\begin{aligned} & \text { 23. SulaymanovZh D. Fusion as a method of } \\ & \text { treatment }\end{aligned}$
for osteochondrosis.Khirurgiyapozvonochnika. 2008;2:36-40. In Russian.

24. Usikov VV, Usikov VD. Mistakes and complications in internal transpedicular fixation in the treatment of patients with unstable spinal injuries, their prevention and management . Travmatologiya $i$ ortopediyaRossii. 2006;1:21-6. In Russian.

25. Cloward RB. The treatment of ruptured intervertebral discs by vertebral body fusion: Indications, operative technique, after care. $J$ Neurosurg1953;10:154-68.

26. Bagby GW. Arthrodesis by the distractioncompression method using a stainless steel implant. Orthopedics. 1988;11:931-4.

27. Vetrile ST, Shvets VV, Krupatkin AI.Indications and tactics for surgical treatment of lumbar osteochondrosis using transpedicular fixation.Khirurgiyapozvonochnika.2004; 4: 40-6.

28. Bozkus H, Chamberlain RH, Perez Garza LE, Crawford NR, Dickman CA. Biomechanical comparison of anterolateral plate, lateral plate, and pedicle screws-rods for enhancing anterolateral lumbar interbody cage stabilization. Spine. 2004;29(6):635-41.

doi.10.1097/01.brs.0000115126.13081.7d

29. Lund T, Oxland TR, Jost B, Cripton P, Grassmann S, Etter C, Nolte LP. Interbody cage stabilization in the lumbar spine: biomechanical evaluation of cage design, posterior instrumentation, and bone density. $J$ Bone Joint Surg $\mathrm{Br}$. 1998;80:351-9.

30. Chen L, Yang H, Tang T. Cage migration in spondylolisthesis treated with posterior lumbar interbody fusion BAK cages. Spine. 2005;30:2171-5.

31. Byval'tsev V.A. Sorokovikov V.A., Kalinin A.A., Belykh E.G. Analysis of the two-year outcomes of anterior cervical fusion using the PCB Evolution plate-cage. Voprosyneyrokhirurgiiim NN Burdenko. 2013;1:37-45. In Russian.

32. Toth JM, Wang M, Estes BT, Scifert JL, Seim HB, Turner AS.Polyetheretherketone as a biomaterial for spinal applications. Biomaterials 2006;27:324-34.
33. Korovesiss P, Papazisis Z, Koureas G, Lambiris E. Rigid, semi rigid versus dynamic instrumentation for degenerative lumbar spine stenosis: A correlative radiological and clinical analysis of shot-term results. Spine 2004;29:735-42.

34. Moore KR, Pinto MR, Butler LM. Degenerative disc disease treated with combined anterior and posterior arthrodesis and posterior instrumentation. Spine. 2002;27:1680-6.

35. Lowe TG, Tahernia AD, O’Brien MF, Smith DA. Unilateral transforaminal posterior lumbar interbody fusion (TLIF): Indications, technique, and2-year results. $J$ Spinal Disord Tech. 2002;15:318.

36. Regev GI, Lee YP, Taylor WR. Nerve injury to the posterior rami medial branch during the insertion of pedicle screws: comparison of mini-open versus percutaneous pedicle screw insertion technics. Spine 2009;34:1239-42.

37. Scheufler KM, Dohmen H, Vougioukas VI. Percutaneous transforaminal lumbar interbody fusion for the treatment of degenerative lumbar instability. Neurosurgery. 2007;60(2):203-12.

38. Taylor J, Pupin P, Delajoux S, Palmer S. Device for intervertebral assisted motion: technique and initial results. Neurosurg Focus. 2007;22:6.

39. Fuchs PD, Lindsey DP, Hsu KY, Zucherman JF, Yerby SA. The use of an interspinosus implant in conjunction with a graded facetectomy procedure.Spine. 2005;30:1266-72.

40. Errico TJ, Kamerlink JR, Quirno M, Samani J, Chomiak RJ. Survivorship of coflexinterlaminarinterspinous implant. SAS Journal. 2009;3:59-67.

41. Lawhorne TW, Girardi FP, Mina CA, Pappou I, Cammisa FP. Treatment of degenerative spondylolisthesis: potential impact of dynamic stabilization based on imaging analysis. Eur Spine $J$. 2009;18:815-22.

42. Cabraja M, Abbushi A, Woiciechowsky C, Kroppenstedt S. The short- and mid-term effect of dynamic interspinous distraction in the treatment of recurrent lumbar facet joint pain. Eur Spine $J$. 2009;18:1686-94.

43. Cho KS, Kang SG, Yoo DS, Huh PW, Kim DS, Lee SB. Risk factors and surgical treatment for symptomatic adjacent segment degeneration after lumbar spine fusion. J Korean Neurosurg Soc. 2009; 46:425-30. 